\title{
IMPLEMENTASI STRATEGI PENANGGULANGAN ILLEGAL LOGGING DI HUTAN LINDUNG SESAOT BKPH RINJANI BARAT RESOTR SESAOT
}

\author{
Oleh:
}

\author{
Maria Goveni Marton, Muhamad Soimin \\ Program Studi Kehutanan Universitas Pendidikan Mandalika \\ Email: venimarton08@gmail.com
}

\begin{abstract}
Abstrak
Tujuan dari penelitian ini adalah Untuk mengetahui strategi dari implementas penanggulangan illegal logging oleh Balai Kesatuan Pengelolah Hutan (BKPH) Rinjani Barat yaitu Resort Sesaot dan untuk mengetahui kendala dari implementasi strategi penanggulangan illegal logging di Balai Kesatuan Pengelolah Hutan (BKPH) Rinjani Barat yaitu Resort Sesaot. Lokasi yang diambil dalam penelitian ini yaitu Hutan Lindung Sesaot, Desa Sesaot Kecamatan Narmada Lombok Barat Nusa Tenggara Barat. Dan waktu penelitian dilakukan mulai pada tanggal 19 Desember 2019 sampai dengan tanggal 18 Januari 2020. Data yang telah diperoleh dilapangan mengenai implementasi strategi penanggulangan illegal logging di Hutan Lindung Sesaot telah dianalisis. Analisis data menggunakan Skala Likert pernyataan yang diajukan mengenai objek perskalaan harus mengandung isi yang akan dinilai responden apakah setuju atau tidak setuju terhadap suatu objek yang jenjang bisa tersusun atas : Sangat setujuh: 5 Setuju : 4 Netral : 3 Kurang setujuh : 2 Sama sekali tidak setujuh : 1. Strategis implementasi penanggulangan illegal longging adalah melakukan penyuluhan, melakukan patroli, membuat destinasi wisata, menjaga kelestarian hutan dari kerusakan akibat ilegal longging, melakukan reiboisasi, membuat peraturan yang ketat terkait cara tepat dalam perlindungan hutan, peningkatan sarana dan prasarana untuk keamanan hutan. Kendala-kendala dalam implementasi penaggulangan illegal longging adalah faktor kemiskinan (setuju 75\%),kurangnnya lapangan perkerjaan (setuju 65\%), kurangnya pemahaman atau SDM masyarakat setempat akan dampak illegal longging (setuju 45\%), adanya aparat yang terlibat dalam praktek illegal longging (netral 40\%), adanya pro dan kontra antara masyarakat yang ingin mencari keuntungan pribadi (setuju 50\%).
\end{abstract}

Keywords : Strategi, Illegal logging, Hutan Lindung

\section{PENDAHULUAN}

Konservasi sumber daya alam (SDA) hayati dan ekosistemnya merupakan pengelolaan sumber daya alam hayati yang pemanfaatannya dilakukan secara bijakasana untuk menjamin kesinambungan persediaanya dengan tetap memelihara dan menigkatkan kualitas keseragamannya dan nilainya. Pada tahun 1990 pemerintah mengeluarkan suatu kebijakan yang mengatur mengenai konservasi SDA hayati yaitu Undang Undang Nomor 5 Tahun 1990 (UU No 5 Tahun 1990) tentang konservasi sumber daya alam hayati Indonesia dan ekosistemnya yang mempunyai kedudukan serta peranan penting bagi kehidupan adalah Karunia Tuhan Yang Maha Esa. Oleh karena itu, perlu dikelolah dan dimanfaatkan secara lestari, selaras, serasi dan seimbang bagi kesejahteraan masyarakat Indonesia khususnya umat manusia pada umumnya, baik masa kini maupun masa depan.

Berdasarkan sifatnya yang luas dan menyangkut kepentingan masyarakat secara keseluruhan, maka upaya konservasi sumber daya alam hayati dan ekosistemnya merupakan tanggung jawab dan kewajiban pemerintah serta masyarakat. Peran serta masyarakat akan diarahkan dan digerakan oleh pemerintah melalui kegiatan yang berdaya guna dan berhasil. Menurut UU No 5 Tahun 1990 pasal 5, kegiatan-kegiatan yang dilaksanakan dalam konservasi SDA hayati dan ekosistemnya perhitungan penyangga sistem kehidupan, pengawetan jenis keanekaragaman tumbuhan dan satwa 
beserta ekosistemnya dan pemanfaatan secara lestari SDA hayati dan ekosistemnya. Hutan Lindung Sesaot merupakan salah satu bagian dari kegiatan konservasi SDA hayati beserta ekosistemnya. UU No 5 Tahun 1990, Hutan Sesaot adalah kawasan pelestarian alam untuk tujuan koleksi tumbuhan yang alami atau buatan, jenis asli dan bukan asli, yang dimaanfaatkan bagi kepentingan penelitian, ilmu pengetahuan, pendidikan, menunjang budidaya, budaya pariwisata dan rekreasi. Adapun tujuan dari Penelitian ini yaitu Untuk mengetahui strategi dari implementas penanggulangan illegal logging oleh Balai Kesatuan Pengelolah Hutan (BKPH) Rinjani Barat yaitu Resort Sesaot dan untuk mengetahui kendala dari implementasi strategi penanggulangan illegal logging di Balai Kesatuan Pengelolah Hutan (BKPH) Rinjani Barat yaitu Resort Sesaot. Permasalahan illegal logging tidak pernah selesai dibicarakan dari tahun ketahun isu tersebut justru semakin memanas karena penyelesaiannya tak kunjung mencapai titik temu. Kasus yang mencuat kepermukaan hanyalah sebagian kecil dari praktik illegal logging yang melibatkan masyarakat, korporat, aparat dan pejabat. kerusakan lingkungan yang di timbulkannya kemudian menyebabkan bencana alam dan bencana ekonomi yang berkesinambungan. Sejauh ini tidak ada satupun peraturan perundangan memberikan pengertian resmi terhadap illegal logging padahal pengertian menjadi sangat penting untuk memberi batasan terhadap tindakan apa yang termasuk lingkup illegal logging. Amir (2011:192) menyatakan implementasi strategi merupakan rangkain aktifitas dan pekerjaan yang dibutuhkan untuk mengeksekusi perencanan stategi. Artinya apa yang dirumuskan pada strategi dan kebijakan akan diterapkan dalam berbagai program kerja.

\section{METODOLOGI PENELITIAN}

\section{a. Lokasi dan Waktu Penelitian}

Lokasi yang diambil dalam penelitian ini yaitu Hutan Lindung Sesaot, Desa Sesaot Kecamatan Narmada Lombok Barat Nusa Tenggara Barat. Dan waktu penelitian dilakukan mulai pada tanggal 19 Desember 2019 sampai dengan tanggal 18 Januari 2020.

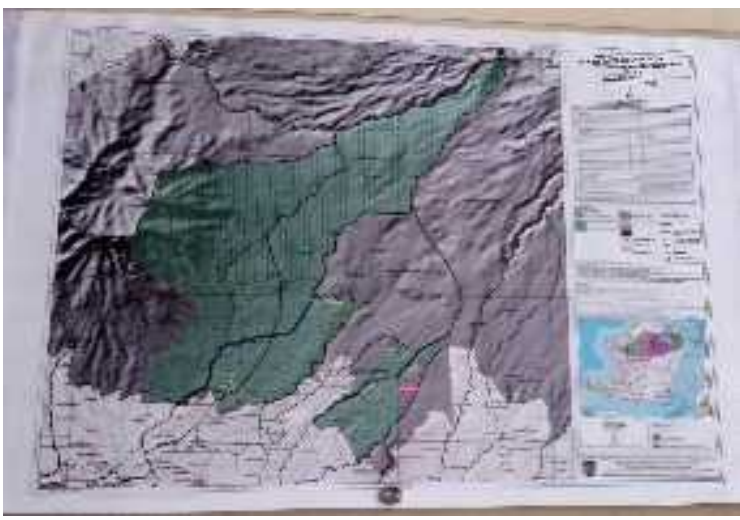

Gambar 1.Peta kawasan Hutan Lindung Sesaot.

\section{b. Alat dan Bahan}

Alat yang digunakan dalam penelitian meliputi alat tulis dan kamera. Bahan yang digunakan adalah kusioner.

\section{c. Cara Kerja}

Dalam penelitian ini teknik pengumpulan data yang digunakan adalah wawancara, observasi dan melalui pustaka.

\section{Wawancara}

Sumber data yang berasal dari informan melalui kata-kata langsung dan Tanya jawab disebut dengan wawancara. Bungin (2007:111) Wawancara mendalam secara umum adalah proses memperoleh keterangan untuk tujuan penelitian dengan cara tanya jawab sambil bertatap muka antara pewawancara dan informan atau orang yang diwawancarai, dimana pewawancara dan informan terlibat dalam kehidupan social yang relative lama dengan menggunakan panduan wawancara. Informan adalah orang yang diwawancarai, dimintai informasi oleh pewawancara. Informan adalah orang yang diperkirakan menguasai dan memahami data, informasi, ataupun fakta dari suatu objek penelitian. Dalam hal ini peneliti mewawancarai beberapa informan yang memahami mengenai implementasi strategi penanggulangan illegal logging pada Hutan Lindung Sesaot. Adapun beberapa informan dalam penelitian ini antara lain: pimpinan BKPH Rinjani Barat, Polisi Hutan (Polhut), kepala desa dan masyarakat. 


\section{Observasi}

Observasi digunakan untuk memperoleh data dengan cara melakukan pengamatan secara sistematis pada obyek penelitian. Pengamatan langsung di lapangan dilakukan untuk mengetahui kondisi dan lokasi penelitian. Nasution dalam kutipan Sugiyono (2011) menyatakan bahwa observasi adalah dasar semua ilmu pengetahuan.Para ilmuan hanya dapat bekerja berdasarkan data,yaitu fakta mengenai dunia kenyataan yang diperoleh melalui observasi. Observasi dalam penelitian ini dilakukan dengan cara pengamatan langsung di Lapangan

\section{Pustaka}

Dilakukan dengan membaca dan mengutip baik secara langsung maupun tidak langsung dari literatur-literatur yang berhubungan langsung dengan penelitian.

\section{d. Analsis Data}

Data yang telah diperoleh dilapangan mengenai implementasi strategi penanggulangan illegal logging di Hutan Lindung Sesaot telah dianalisis. Analisis data menggunakan Skala Likert, pernyataan yang diajukan mengenai objek perskalaan harus mengandung isi yang akan dinilai responden apakah setuju atau tidak setuju terhadap suatu objek yang jenjang bisa tersusun atas: Sangat setujuh: 5 Setuju : 4 Netral : 3 Kurang setujuh : 2 Sama sekali tidak setujuh : 1

\section{HASIL dan PEMBAHASAN}

\section{a. Strategi Impementasi Penanggulangan Illegal Logging}

Salah satu strategi implementasi enanggulangan illegal ogging adalah mengenai pengamanan hutan yaitu pengoptimalan polisi hutan (polhut) pengoptimalan polisi hutan (polhut) tersebut mengenai fungsi dalam pengamanan hutan baik dari kebakaran hutan maupun illegal logging,menurut pengurus BKPH rinjani barat yaitu resot sesaot menjelaskan bahwa dalam rangka meningkatkan kesiapsiagaan polisi hutan,aparat pemerintah setempat mereka sudah melalukan berbagai kegiatan yaitu;
1. secara interen melakukan patroli secara rutin di dalam kawasan maupun diluar kawasan hutan.

2. Melakukan penyuluhan kepada masyarakat sekitar hutan dari pengelola kawasan untuk bekerja sama dalam penanganan dan pencegahan illegal logging.

Tabel 1. faktor penyebab terjadinya illegal logging

\begin{tabular}{|c|c|c|c|c|c|c|}
\hline $\begin{array}{l}\mathbf{N} \\
\mathbf{o}\end{array}$ & Pertanyaan & SS & $\mathbf{S}$ & $\mathbf{N}$ & $\begin{array}{l}\mathbf{K} \\
\mathbf{S}\end{array}$ & $\begin{array}{l}\mathbf{T} \\
\mathbf{S}\end{array}$ \\
\hline 1 & $\begin{array}{l}\text { Faktor kemiskinan yang } \\
\text { terjadi di masyarakat }\end{array}$ & & & & & \\
\hline & Jumlah & & 15 & 4 & & 1 \\
\hline & Presentase & & $\begin{array}{l}75 \\
\%\end{array}$ & $\begin{array}{l}20 \\
\%\end{array}$ & & $\begin{array}{l}5 \\
\%\end{array}$ \\
\hline 2 & $\begin{array}{l}\text { Kurangnya lapangan } \\
\text { kerja dan pendapatan } \\
\text { masyarakat setempat }\end{array}$ & & & & & \\
\hline & Jumlah & 4 & 13 & 2 & & 1 \\
\hline & Presentase & $\begin{array}{l}20 \\
\%\end{array}$ & $\begin{array}{l}65 \\
\%\end{array}$ & $\begin{array}{l}10 \\
\%\end{array}$ & & $\begin{array}{l}5 \\
\%\end{array}$ \\
\hline 3 & $\begin{array}{ll}\text { Lemahnya } & \text { peran } \\
\text { penegak hokum } & \text { dalam } \\
\text { menangani } & \text { illegal } \\
\text { logging } & \end{array}$ & & & & & \\
\hline & Jumlah & & & 2 & 11 & 7 \\
\hline & Presentase & & & $\begin{array}{l}10 \\
\%\end{array}$ & $\begin{array}{l}55 \\
\%\end{array}$ & $\begin{array}{l}35 \\
\%\end{array}$ \\
\hline
\end{tabular}

Data primer : pengeolaan data 2020

a. Dari data tabel diatas yaitu tabel 1, faktor penyebab illegal logging yang paling tinggi itu karena faktor kemiskinan terlihat dari jawaban yang paling tinggi yaitu setuju dengan nilai presentase $75 \%$, netral $20 \%$, dan tidak setuju 5\%. Dari jawaban diatas faktor ekonomi dan pengangguran bahwa masih banyak masyarakat yang tidak memiliki pekerjaan tetap, mereka menggantungkan hidup mereka dari hasi bertani dan berkebun dan itu belum mencukupi untuk memenuhi kebutuhan mereka. 
b. Faktor kuranganya lapangan pekerjaan dan pendapatan dengan tingkatan jawaban paling tinggi yaitu setuju $65 \%$, netral 10\% dan tidak setuju 5\%, kurangan lapangan pekerjaan dan pendapatan faktor penyebab terjadinya illegal logging. Faktor ekonomi dan pengengguran meninggkat. Disini peran pemerintah setempat sangat di perlukan terkait bagaimana cara pemerintah untuk menanggulangi masalah pengangguran dalam menciptakan lapangan kerja untuk masyarakat setempat. Dan itu sudah dilakukan oleh pemerintah setempat dengan memanfaatkan keberadaan Kawasan Taman Hutan Raya Sesaot dengar memberi peluang kepada masyarakat membuka lapak dengan berbagai macam jualan dalam kawasan hutan yang sudah di tentukan oleh pemerintah setempat. Dan kurang lebih ada seratus orang yang sudah bekerja dalam kawasan hutan Sesaot. Karena Taman Hutan Raya Sesaot sudah menjdi tempat wisata.

c. Lemahnya peran penegak hukum dengan tingkatan jawaban paling tinggi yaitu kurang setuju dengan presentase $55 \%$, tidak setuju $35 \%$ dan netral $10 \%$. Dilihat dari jawabannya peran penegak hukum yaitu pemerintah setempat sudah berjalan dengan baik, hanya kerena masyarakat sendiri yang masih berani untuk melakukan tindakan praktik illegal logging demi terpenuhnya kebutuhan hidup tanpa memikirkan akibat dan dampak dari illegal logging itu.

\section{KESIMPULAN}

Kesimpulan pada penelitian ini adalah sebagai berikut : implementasi strategi penanggulangan illegal logging Hutan Lindung Sesaot di BKPH Rinjani Barat kecamatan Narmada. Strategis implementasi penanggulangan illegal longging adalah melakukan penyuluhan, melakukan patroli, membuat destinasi wisata, menjaga kelestarian hutan dari kerusakan akibat ilegal longging, melakukan reiboisasi, membuat peraturan yang ketat terkait cara tepat dalam perlindungan hutan, peningkatan sarana dan prasarana untuk keamanan hutan. Kendalakendala dalam implementasi penaggulangan illegal longging adalah faktor kemiskinan (setuju 75\%),kurangnnya lapangan perkerjaan (setuju 65\%), kurangnya pemahaman atau SDM masyarakat setempat akan dampak illegal longging (setuju 45\%), adanya aparat yang terlibat dalam praktek illegal longging (netral $40 \%$ ), adanya pro dan kontra antara masyarakat yang ingin mencari keuntungan pribadi (setuju $50 \%)$

\section{DAFTAR PUSAKA}

Adom. 2011. Manajemen strategi untuk manejemen pendidikan. Bandung : alfabeta

Allison, Michael dan Jude Kaye. 2013. Perencanaan Strategi bagi OrganisasiNirlaba. Jakarta : Yayasan Pustaka Obor Jakarta

Amir, taufik m. 2011 Manajemen Strategi Konsep dan Aplkasi. Jakarta: PT raja grafindo Persada

Amirullah. 2015. Pengantar Manajemen. Jakarta: Mitra Wacana Media

Bryso, John M. 1999. Perencanaan Strategi bagi Organisasi Sosial. Yogyakarta : Pustaka Pelajar konsep. 2005. Manajemen strategi :

Davit, Fred R. 2005. Manajemen Strategi : Konsep. Jakarta : Salemba Empat

Heene, dkk. 2010. Manajemen Strategik Keorganisasian Publik. Bandung: PT Rafika Aditama

Hubeis, Najib. 2008. Manajemen Strategi Dalam Pengembangan Daya Saing Organisasi. Jakarta : PT elex Media Komputindo

Husein, Umar. 2010. Riset Pemasaran dan Bisnis. Jakarta : Gramedia Pustaka Utama

Kartodiharjo, H. 2006. Kebijakan pengelolaan hutan. Yogyakarta : magister Ilmu Kehutanan Universitas Gadjah Mada

Moleong, Lexy J. 2011. Metodologi penelitian kuanlitatif. Bandung: PT Remaja Rodaskarya

Pearch dan Robinson. 1997. Manajemen strategi. Jakarta : Binarupa Aksara Utomo, Hargo. 1993. E-book. Manajemen strategik, jakarta: Gunadarma 
Taufigurrokhman. 2016. Mengenala Menajemen Strategi. Jakarta: Universitas Prof. Dr. Moestopo Beragama

Dokumen-dokumen:

Undang-Undang Nomor 5 Tahun 1999

Undang-Undang Nomor 41 Tahun 1999

Undang-Undang Nomor 19 Tahun 1994

Intruksi Presiden Nomor 5 Tahun 2001

Sumber Wabsite:

http/kapassc.blogspot.com/2013/hutan sesaot.html. di download pada tanggal 27 januari 2020.

http/m.rri.co.id/post/berita/72664/budaya dan wisata desasesaot.lombokbarat.raihista2019.html. di download pada tanggal 27 januari 2020

http/www.katanews.com/perekonomia desasesaot 2017.htm di download pada tanggal 26 februari 2020

www.narmada,Co,id. Didownload pada tanggal 26 februari 2020.

www. Desa Sesaot.id. 